\title{
Supramolecular Structure of the Shigella Type III Secretion Machinery
}

\author{
Tomoko MORITA-ISHIHARA* \\ Division of Bacteriology, National Institute of Infectious Diseases, Toyama 1-23-1, Shinjuku-ku, Tokyo 162-8640, Japan
}

Received for publication, January 30, 2007

Recently, the cross-talk between pathogenic bacteria and the intestinal epithelial cells has been a topic of discussion. For infecting intestinal epithelial cells, pathogenic gram-negative bacteria secrete virulence factors directly into the cell and then use them to modulate the various functions of the epithelial cell. In the process, the bacterium uses the type III secretion machinery to directly interact with the epithelial cell. In 1998, Kubori et al. purified the type III secretion machinery from Salmonella for the first time and clarified its supramolecular structure. It has since been identified in many other pathogenic bacteria. The analysis of type III secretion machinery has advanced rapidly, and the mystery behind host cell infection by pathogenic bacteria is gradually becoming clear. In this article, the structure and function of the Shigella type III secretion machinery are reviewed.

Key words: Shigella; type III secretion machinery; host-bacteria interaction

\section{INTRODUCTION}

Gram-negative bacteria use a protein secretion system for releasing the proteins produced by them, for example, virulence factors, into the extracellular environment or transporting such proteins into the host cell $(14,27)$. The protein secretion systems of gram-negative bacteria are classified into types I-IV (Fig. 1). Further, these systems are roughly classified as sec-dependent (type II) and the sec-independent (types I, III, and IV) secretion systems. The type I secretion system is exemplified by the Escherichia coli alpha-hemolysin secretion system. The type II secretion is the primary pathway for the secretion of extracellular degradative enzymes by gram-negative bacteria. The type III and type IV secretion systems are related to the transportation/secretion of the virulence factors that are also referred to as effectors. The type III secretion system and the flagellum share a common origin. The type IV secretion system is derived from conjugative DNA transfer systems. The type III secretion system (TTSS) is present in many gramnegative animal and plant pathogenic bacteria. The machinery of the TTSS (type III secretion machinery, TTSM) is involved in the direct transport of the effectors from the bacterial cell into the host cell through a continuous molecular channel. The TTSM plays an important role in the first cross-talk, i.e., the physical contact between the bacteria and the host cell, during a host pathogen interaction. The TTSM was first isolated from Salmonella typhimurium by Kubori et al. in 1998,

*Corresponding author. Mailing address: Division of Bacteriology, National Institute of Infectious Diseases, Toyama 1-23-1 Shinjuku-ku, Tokyo 162-8640, Japan. E-mail: ishihara@nih.go.jp and the supramolecular structure was clarified (18). The use of transmission electron microscopy (TEM) to visualize the TTSM was a landmark achievement in the field. Since then, the TTSM has been identified and visualized by TEM in many other pathogenic bacteria, including Shigella flexneri, Yersinia spp., and enteropathogenic Escherichia coli (EPEC) (6, 17, 18, 35, 38 , 46). Using the Shigella TTSS as an example, this review will present a brief overview of the TTSS while focusing on the mechanism of secretion and the assembly/architecture of the secretion system.

Shigella are highly adapted to human pathogens that cause bacillary dysentery (also referred to as shigellosis). The prominent pathogenic feature of Shigella is the ability to invade a variety of host cells during infection of the intestinal mucosa, including enterocytes, macrophages, dendritic cells, and neutrophils. When Shigella reaches the colon and rectum, the bacteria translocate through the epithelial barrier by way of the $M$ cells that overlie the solitary lymphoid nodules (29). Once they reach the underlying M cells, Shigella invade the resident macrophages and induce cell death through apoptosis that is mediated by effectors secreted via the TTSM (Fig. 2). Shigella released from the killed macrophages enter the surrounding enterocytes through their basolateral surface by inducing membrane ruffling and macro-pinocytosis. Once the bacterium is surrounded by a phagocytic vacuole, it immediately disrupts the vacuole and escapes into the cytoplasm. Shigella multiply in the cytoplasm and move about by inducing actin polymerization at one pole of the bacteria, allowing intracellular bacteria to spread within the 


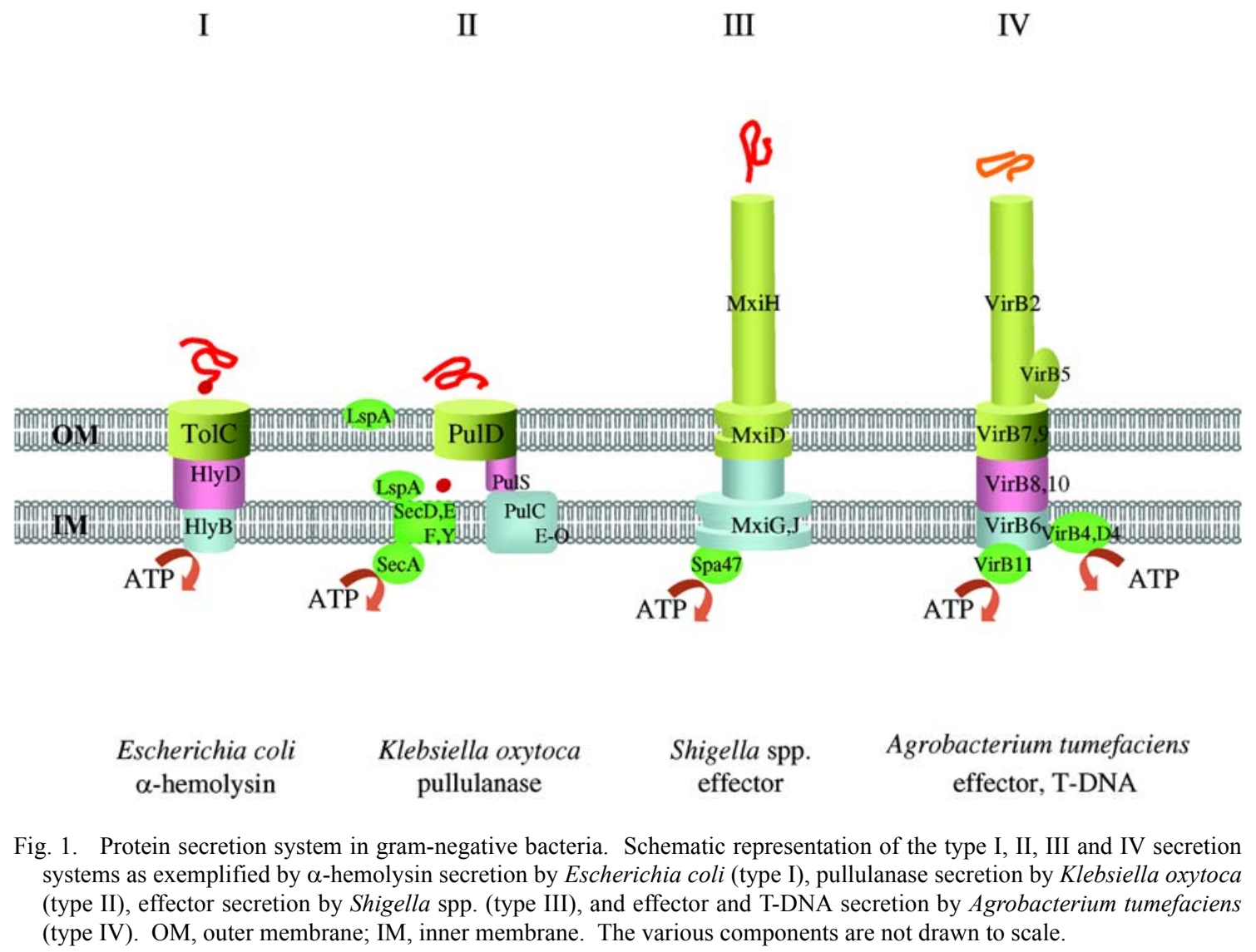

cytoplasm as well as into the adjacent epithelial cells Finally, Shigella infection destroys the epithelial tissue and causes inflammatory bleeding diarrhea (Fig. 2). During Shigella infection, when Shigella comes in contact with the host cell, the bacterium inserts the needle tip of the TTSM into the host cell membrane, and injects the effectors directly into the cytoplasm of the host cell through the needle. As a result, the effector activates signal transmission in the host cell; in addition, it induces rearrangement of the actin cytoskeleton in the epithelial cells. Thus, through modification and control of higher cell functions, the Shigella performs various tasks such as phagocytosis that are necessary to infect the host cell (Fig. 2) (8, 11, 24, 25, 29, 37, 42-44).

\section{STRUCTURE OF THE TYPE III SECRETION MACHINERY}

\section{Overview}

Shigella type III secretion machinery (TTSM) is a needle-like structure through the inner membrane, the peptidoglycan layer, and outer membrane of the bacterial envelope (Figs. 3 and 4). TTSM comprises three distinct parts - basal body, needle and cytoplasmic ring (C-ring)
$(10,13,14)$. The basal body is embedded in the bacterial membrane, while the needle protrudes from the bacterial surface. The C-ring is located beneath the basal body in the cytoplasm. The basic morphological structure of the TTSM closely resembles that of the flagellar hook, basal body and C-ring (Fig. 4) (6, 18, 20, 35, 38).

Genetic and structural studies have indicated further that the TTSM of Shigella flexneri is composed of 20 proteins encoded by the mxi and spa genes on the large 230-kb plasmid (Table 1). The mxi and spa genes in their respective operons exist as a part of a $31-k b$ pathogenicity island where other virulence operons such as ipa, ipg and ics are also present upstream of the mxi operon $(2-4,30-34,45)$.

\section{The basal body}

The basal body is composed of a double ring associated with the outer bacterial membrane (upper ring), a double ring associated with the inner bacterial membrane (lower ring), and a rod that traverses the periplasmic space (Fig. 3) $(6,38)$. It closely resembles the flagellar basal body $(6,18,20,35,38)$. Supramolecular structure analysis has revealed that the 


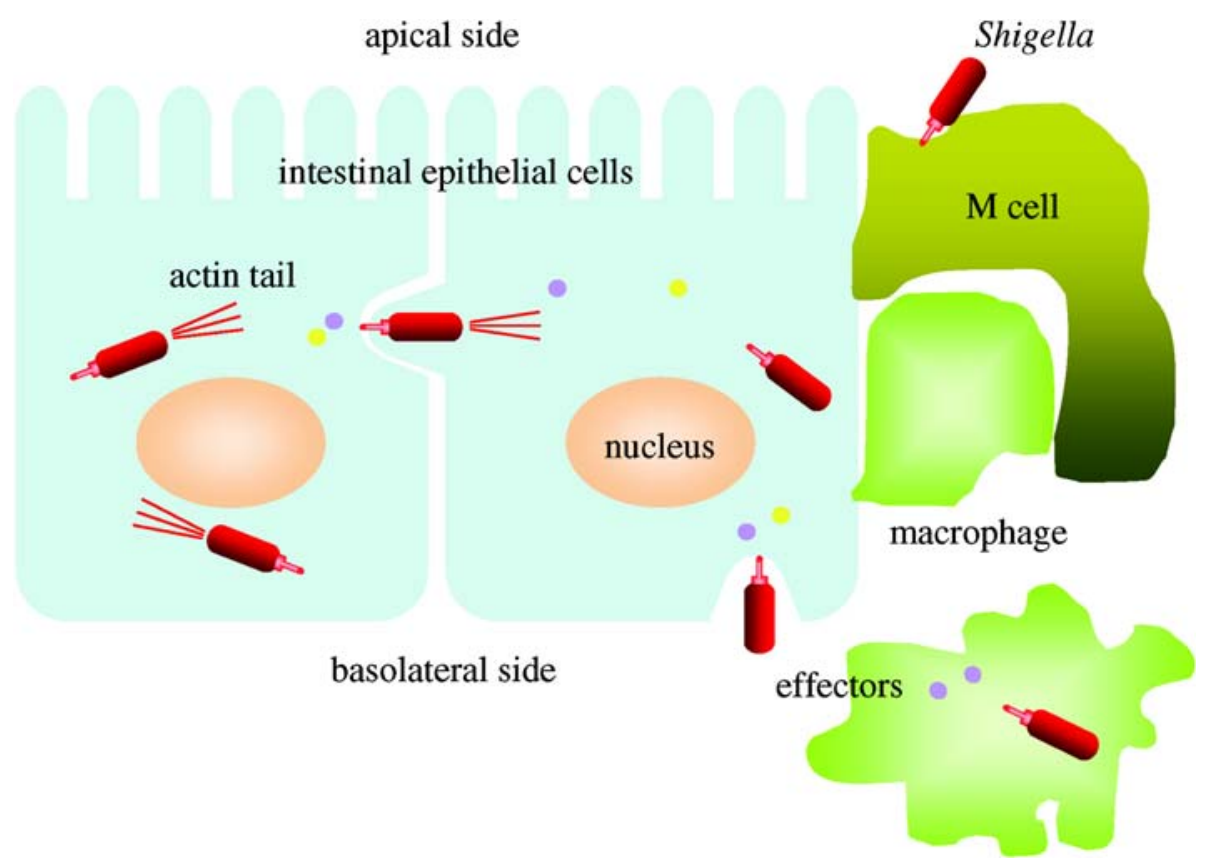

Fig. 2. A simplified model for the infection of intestinal epithelial cells by Shigella. Schematic representation of the steps that lead to translocation through the intestinal epithelial barrier and invasion by Shigella.

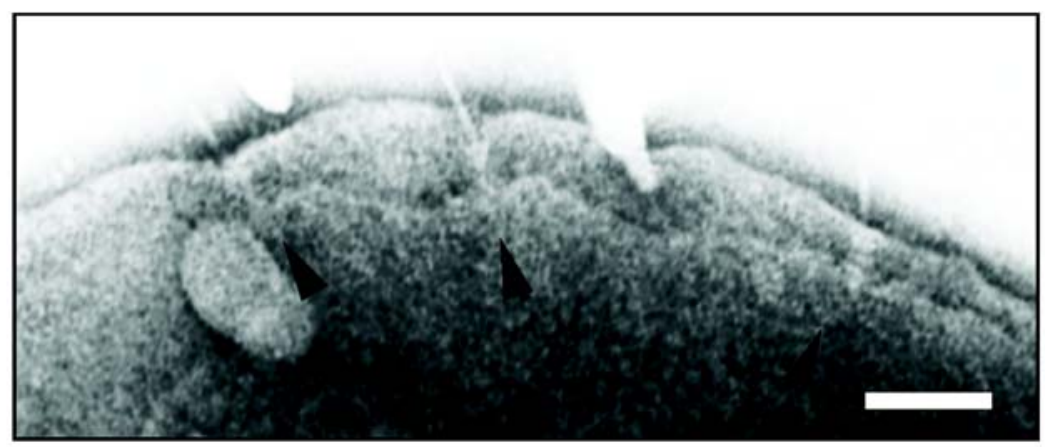

\section{TTSM without C-ring}
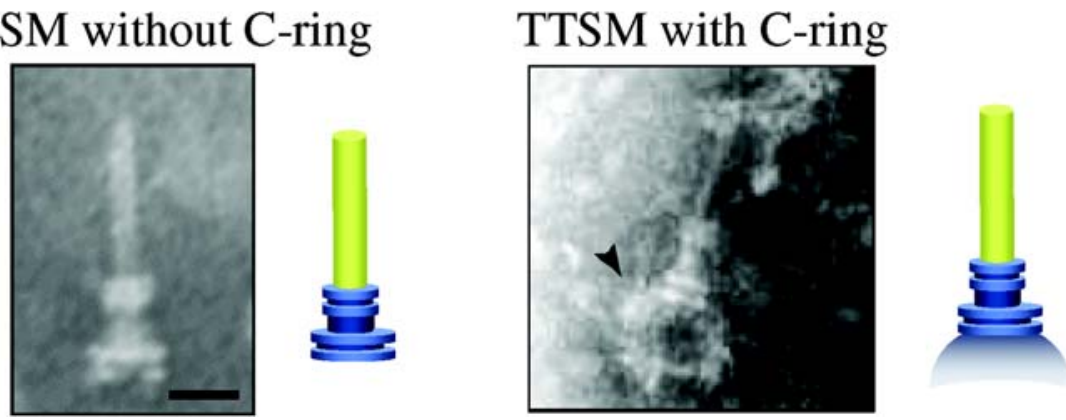

Fig. 3. Electron micrograph of Shigella type III secretion machinery. Osmotically shocked cells. The arrowheads indicate the type III secretion machinery on the bacterial envelope (upper panel). Purified type III secretion machinery (TTSM) without (left)/with (right) a cross-linking reagent. The arrowhead indicates the C-ring (lower panel). Scale bar, $50 \mathrm{~nm}$. 


\section{Type III secretion machinery}

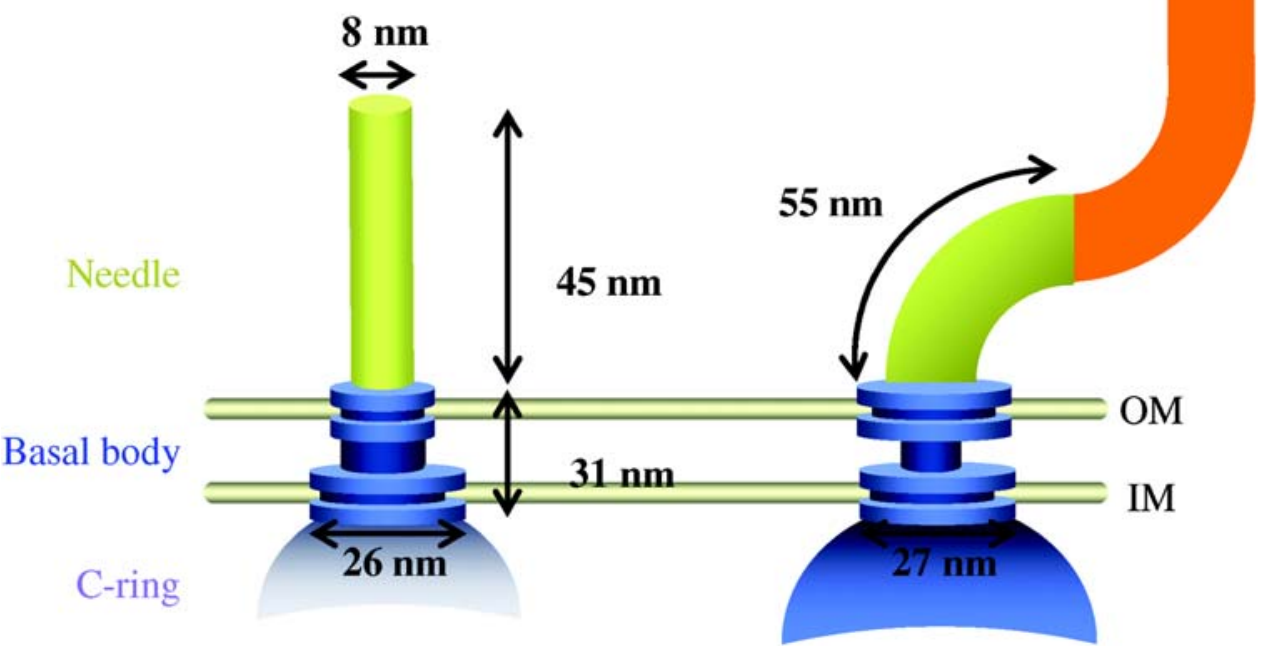

Flagella

Filament

Hook

Basal body

C-ring

Fig. 4. Comparison of type III secretion machinery and flagella. OM, outer membrane; IM, inner membrane.

approximate width and thickness of the upper ring are 9.5 $\mathrm{nm}$ and $15 \mathrm{~nm}$ and those of the lower ring are $11 \mathrm{~nm}$ and $26 \mathrm{~nm}$, respectively; the overall length of the basal body is approximately $31 \mathrm{~nm}$. Moreover, it has been reported that the basal body is composed of three protein components-MxiD, MxiG, and MxiJ (38). Based on the analysis of a homologous bacterial protein derived from Salmonella, it is estimated that the upper ring is composed of only one protein, MxiD, and the lower ring and the rod are composed of two proteins, MxiG and MxiJ.

\section{The needle}

The needle is a needle-like appendage that protrudes from the bacterial membrane envelope (Figs. 3 and 4) (6, 38 ), and plays an important part as the "injection needle" that transports the effectors into the host cell. It is thought that the needle corresponds to the flagellar hook. The flagellar hook is a cylindrical curved structure that functions as a universal joint between the basal body and the flagellar filament (20). On the other hand, the needle of Shigella TTSM is a straight structure $(6,38)$. Although they are different morphologically, they are similar in that both extend from the basal body to the exterior of the outer membrane. Furthermore, there is functional similarity in the transport of components through the hook during the assembly of the flagellum fiber and the transport of the effectors through the needle of Shigella TTSM.

The needle of TTSM is composed of MxiH $(6,38)$. It is thought that $\mathrm{MxiH}$ is transported to the exterior of the outer membrane through the basal body; subsequently, the needle is formed as a result of polymerization. Hyperfine structure analysis has revealed the needle to be approximately $45 \mathrm{~nm}$ in length and $8 \mathrm{~nm}$ in width. The needle length of Shigella wild-type is strictly restricted to a narrow range with a mean value of approximately 45 $\mathrm{nm}(21,40)$. Studies on purified TTSM obtained from the spa32 deletion mutant of Shigella, have shown that the length of the needle is not restricted and varies in length from 45 to $1,150 \mathrm{~nm}$ (40). This suggests that Spa32 plays a role in controlling the needle length. A protein with functions similar to those of Spa32 is found in a TTSM-possessing gram-negative bacteria not belonging to the Shigella spp. $(15,19,21,28,36,39)$. It has been reported that Salmonella InvJ and Yersinia YscP control the needle length, like Spa32, with which they share amino acid homology $(16,36)$. Analysis has shown that the molecular mechanism by which the needle length is controlled is most advanced in YscP (16). Deletions and insertions in $y s c P$ have been shown to result in shorter and longer needles, respectively. Additionally a linear correlation was observed between the size of the YscP protein and the length of the needle 
Table 1. List of proteins of the type III secretion machinery and flagella

\begin{tabular}{|c|c|c|c|c|c|}
\hline Shigella & $\begin{array}{l}\text { Salmonella } \\
\text { SPI-1 }\end{array}$ & $\begin{array}{l}\text { Yersinia } \\
\text { Ysc }\end{array}$ & Pseudomonas & $\begin{array}{c}\text { flagella } \\
(\text { Salmonella })\end{array}$ & Function \\
\hline MxiG & $\operatorname{PrgH}$ & & & & Basal body component \\
\hline MxiH & PrgI & YscF & & & Needle component \\
\hline MxiI & PrgJ & & & & Needle component \\
\hline MxiJ & PrgK & YscJ & HrcJ & FliF & Basal body component \\
\hline MxiK & OrgB & YscK & & & \\
\hline MxiN & OrgA & YscL & & & \\
\hline MxiL & & & & & \\
\hline MxiM & InvH & YscW & & $\mathrm{FlgH}$ & \\
\hline MxiE & $\operatorname{InvF}$ & & & & Transcription factor \\
\hline MxiD & InvG & YscC & $\mathrm{HrcC}$ & & Basal body component \\
\hline MxiC & InvE & & & & \\
\hline MxiA & InvA & lcrD & $\mathrm{HrcV}$ & FlhA & Export channel \\
\hline Spa15 & InvB & & HrpQ & & Chaperone \\
\hline Spa47 & InvC & $\mathrm{YscN}$ & $\mathrm{HrcN}$ & FliI & ATPase, Transport energy \\
\hline Spa13 & InvI & $\mathrm{YscO}$ & $\mathrm{HrpO}$ & FliJ & Chaperone \\
\hline Spa32 & InvJ & YscP & HrpP & FliK & Molecular ruler for needle length \\
\hline Spa33 & $\mathrm{SpaO}$ & YscQ & HrcQ & FliN & C-ring \\
\hline Spa24 & SpaP & YscR & HrcR & FliP & Export channel \\
\hline Spa9 & SpaQ & YscS & $\mathrm{HrcS}$ & FliQ & Export channel \\
\hline Spa29 & SpaR & YscT & HrcT & FliR & Export channel \\
\hline Spa40 & SpaS & YscU & $\mathrm{HrcU}$ & FlhB & Export channel \\
\hline
\end{tabular}

structure, suggesting that the protein functions as a molecular ruler $(16,22)$. Like YscP, Spa32 might also function as a "molecular ruler" by maintaining the needle length constant.

It has been suggested that MxiK, MxiN, and Spa47 are necessary for the TTSM formation $(15,23,38)$. According to Jouihri, Shigella MxiN is necessary for transporting MxiH, a major needle component, and Shigella MxiK is necessary for transporting Mxil, one of the needle components (15). Research on Shigella TTSM, Salmonella TTSM and the flagellar basal body has revealed that Shigella Spa47 and its homologues are localized in the vicinity of the basal body in the cytoplasm and functions as an ATPase that supplies the energy necessary for the transport of needle components and effectors. Salmonella InvC, an Spa47 homolog, induces chaperone release and unfolding of the cognate secreted protein in an ATP-dependent manner (1).

\section{The C-ring}

The C-ring is a centroclinal structure that is located beneath the basal body of the TTSM in the cytoplasm (23). Electron microscope images have clarified the details of this structure, recently (Figs. 3 and 4).

In many gram-negative bacteria, the macromolecular structure, which is reminiscent of the C-ring structure of the flagellar hook-basal body, has been postulated to be located beneath the basal body of $\operatorname{TTSM}(7,9)$. In
Shigella, based on the observation of osmotic-shocked bacterial envelopes by TEM, it has been reported that the TTSM has an additional C-ring-like structure-referred to as the bulb-on the cytoplasmic side of the inner membrane $(5,23)$. However, there has been no clear demonstration of the C-ring structure in extensively purified TTSM. Indeed, purified TTSM from S. flexneri, S. typhimurium, or EPEC consistently failed to show a Cring-like macromolecular structure $(6,17,18,35,38$, 46). This suggests that the $\mathrm{C}$-ring structure may be lost through the process of TTSM purification during which such a macromolecular structure might be easily detached from the basal body. Since the purification of the C-ring is difficult, the analysis of its structure and function has not progressed much. Recently, however, using TEM analysis, it was shown that TTSM purified from Shigella treated with cross-linking reagents possessed a C-ring-like structure (Fig. 3, arrow head) (23). It is thought that the detachment of the C-ring from the basal body can be proved by stabilizing the bacterial envelope containing the TTSM with cross-linking reagents.

The C-ring morphologically resembles the structure called the C-ring, assembled beneath the flagellar basal body. A protein that shares amino acid homology with FliN, a component of the flagellar C-ring, is found in many gram-negative bacteria $(20,47)$. The Spa33 protein of Shigella shows a moderate amino acid 


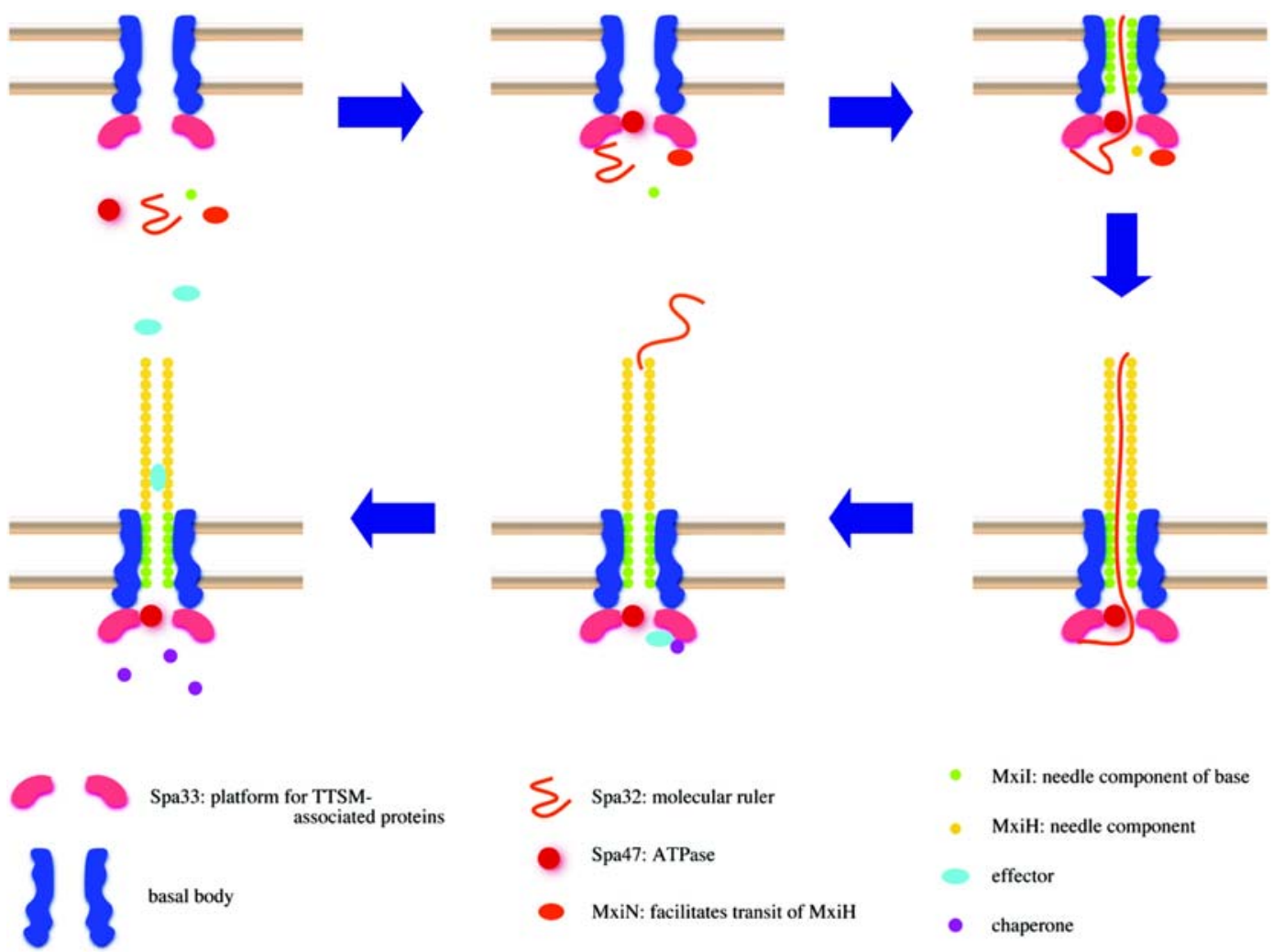

Fig. 5. A model of the morphological pathway for the formation of type III secretion machinery.

homology with FliN. By TEM analysis, it was clarified that the Spa33 is one of the components of the C-ringlike structure (23).

The C-ring compartment of TTSM is assumed to be involved in recognition of the secreted signals carried by effectors and to be responsible for the promiscuous character of TTSM regarding heterologous secreted proteins. With regard to Shigella, it is just conceivable that the $\mathrm{C}$-ring serves as a platform mediating the transit of proteins to be transported through the TTSM basal body. However, the mechanisms underlying the recognition and export of proteins via the TTSM components remain essentially unknown $(7,12,26,41)$.

\section{Morphologic pathway for the formation of the type III} secretion machinery

A model of the morphologic pathway for the formation of Shigella TTSM is illustrated in Fig. 5. Analogous with the formation of the basal body of the Salmonella flagellum or TTSM $(21,36)$, several Shigella Mxi proteins are anchored to the inner and outer membranes and build up the basal body $(6,38,46)$. The C-ring compartment, which is possibly composed of
Spa33, might be necessary for the formation of a functional secretion apparatus, since the spa 33 mutant is incapable of forming the needle structure or mediating the secretion of effector proteins (23). C-ring formation might take place after formation of the basal body, since in the absence of Spa33 the bacterium is still capable of forming a defective basal body structure within the envelope. The functional basal body may subsequently mediate the translocation of MxiI (a putative needle component embedded in the basal body) and MxiH (the major surface-exposed needle component) to extend the needle structure with the aid of Spa47 ATPase, in which Spa32 may act as a molecular ruler, similar to Yersinia YscP, to regulate the length of the needle $(6,15,21,38$, 40). The formation of a functional TTSM may eventually be accomplished by releasing Spa32 from the needle into the space surrounding the bacteria, which may be followed by the translocation of effector proteins (IpaB, IpaC, and IpaD) via the TTSM to act as the molecular cap at the tip of the needle.

\section{CONCLUSION}

It is expected that the elucidation of the structure and 
function of the TTSM present in many gram-negative bacteria, including Shigella, would facilitate the development of new medicines that specifically control the secretion mechanism of bacterial virulence factors. However, the mechanisms underlying the recognition and export of proteins via the TTSM components remain essentially unknown. It is thought that clarification of the structure and function of the TTSM at the molecular level may contribute to the development of a vaccine or drug that targets the TTSM by blocking the transportation of the effectors.

\section{REFERENCES}

(1) Akeda Y, Galan JE. 2005. Chaperone release and unfolding of substrates in type III secretion. Nature 437: 911-915.

(2) Allaoui A, Sansonetti PJ, Menard R, Barzu S, Mounier J, Phalipon A, Parsot C. 1995. MxiG, a membrane protein required for secretion of Shigella spp. Ipa invasins: involvement in entry into epithelial cells and in intercellular dissemination. Mol Microbiol 17: 461470.

(3) Allaoui A, Sansonetti PJ, Parsot C. 1992. MxiJ, a lipoprotein involved in secretion of Shigella Ipa invasins, is homologous to YscJ, a secretion factor of the Yersinia Yop proteins. J Bacteriol 174: 7661-7669.

(4) Allaoui A, Sansonetti PJ, Parsot C. 1993. MxiD, an outer membrane protein necessary for the secretion of the Shigella flexneri lpa invasins. Mol Microbiol 7: 59-68.

(5) Blocker A, Gounon P, Larquet E, Niebuhr K, Cabiaux V, Parsot C, Sansonetti P. 1999. The tripartite type III secreton of Shigella flexneri inserts IpaB and IpaC into host membranes. J Cell Biol 147: 683-693.

(6) Blocker A, Jouihri N, Larquet E, Gounon P, Ebel F, Parsot C, Sansonetti P, Allaoui A. 2001. Structure and composition of the Shigella flexneri "needle complex", a part of its type III secreton. Mol Microbiol 39: 652663.

(7) Blocker A, Komoriya K, Aizawa S. 2003. Type III secretion systems and bacterial flagella: insights into their function from structural similarities. Proc Natl Acad Sci USA 100: 3027-3030.

(8) Bourdet-Sicard R, Rudiger M, Jockusch BM, Gounon P, Sansonetti PJ, Nhieu GT. 1999. Binding of the Shigella protein IpaA to vinculin induces F-actin depolymerization. EMBO J 18: 5853-5862.

(9) Cornelis GR. 2006. The type III secretion injectisome. Nat Rev Microbiol 4: 811-825.

(10) Cornelis GR, Van Gijsegem F. 2000. Assembly and function of type III secretory systems. Annu Rev Microbiol 54: 735-774.

(11) Cossart P, Sansonetti PJ. 2004. Bacterial invasion: the paradigms of enteroinvasive pathogens. Science 304: 242-248.

(12) Ghosh P. 2004. Process of protein transport by the type
III secretion system. Microbiol Mol Biol Rev 68: 771795.

(13) He SY, Nomura K, Whittam TS. 2004. Type III protein secretion mechanism in mammalian and plant pathogens. Biochim Biophys Acta 1694: 181-206.

(14) Hueck CJ. 1998. Type III protein secretion systems in bacterial pathogens of animals and plants. Microbiol Mol Biol Rev 62: 379-433.

(15) Jouihri N, Sory MP, Page AL, Gounon P, Parsot C, Allaoui A. 2003. MxiK and MxiN interact with the Spa47 ATPase and are required for transit of the needle components MxiH and MxiI, but not of Ipa proteins, through the type III secretion apparatus of Shigella flexneri. Mol Microbiol 49: 755-767.

(16) Journet L, Agrain C, Broz P, Cornelis GR. 2003. The needle length of bacterial injectisomes is determined by a molecular ruler. Science 302: 1757-1760.

(17) Kimbrough TG, Miller SI. 2000. Contribution of Salmonella typhimurium type III secretion components to needle complex formation. Proc Natl Acad Sci USA 97: 11008-11013.

(18) Kubori T, Matsushima Y, Nakamura D, Uralil J, LaraTejero M, Sukhan A, Galan JE, Aizawa SI. 1998. Supramolecular structure of the Salmonella typhimurium type III protein secretion system. Science 280: 602-605.

(19) Kubori T, Sukhan A, Aizawa SI, Galan JE. 2000. Molecular characterization and assembly of the needle complex of the Salmonella typhimurium type III protein secretion system. Proc Natl Acad Sci USA 97: 10225-10230.

(20) Macnab RM. 2003. How bacteria assemble flagella. Annu Rev Microbiol 57: 77-100.

(21) Magdalena J, Hachani A, Chamekh M, Jouihri N, Gounon P, Blocker A, Allaoui A. 2002. Spa32 regulates a switch in substrate specificity of the type III secreton of Shigella flexneri from needle components to Ipa proteins. J Bacteriol 184: 3433-3441.

(22) Minamino T, Pugsley AP. 2005. Measure for measure in the control of type III secretion hook and needle length. Mol Microbiol 56: 303-308.

(23) Morita-Ishihara T, Ogawa M, Sagara H, Yoshida M, Katayama E, Sasakawa C. 2006. Shigella Spa33 is an essential C-ring component of type III secretion machinery. J Biol Chem 281: 599-607.

(24) Niebuhr K, Jouihri N, Allaoui A, Gounon P, Sansonetti PJ, Parsot C. 2000. IpgD, a protein secreted by the type III secretion machinery of Shigella flexneri, is chaperoned by IpgE and implicated in entry focus formation. Mol Microbiol 38: 8-19.

(25) Ohya K, Handa Y, Ogawa M, Suzuki M, Sasakawa C. 2005. IpgB1 is a novel Shigella effector protein involved in bacterial invasion of host cells: Its activity to promote membrane ruffling via RAC1 and CDC42 activation. J Biol Chem 280: 24022-24034.

(26) Plano GV, Day JB, Ferracci F. 2001. Type III export: new uses for an old pathway. Mol Microbiol 40: 284 293. 
(27) Remaut H, Waksman G. 2004. Structural biology of bacterial pathogenesis. Curr Opin Struct Biol 14: 161170.

(28) Russmann H, Kubori T, Sauer J, Galan JE. 2002. Molecular and functional analysis of the type III secretion signal of the Salmonella enterica InvJ protein. Mol Microbiol 46: 769-779.

(29) Sansonetti PJ. 2001. Rupture, invasion and inflammatory destruction of the intestinal barrier by Shigella, making sense of prokaryote-eukaryote crosstalks. FEMS Microbiol Rev 25: 3-14.

(30) Sansonetti PJ, Hale TL, Dammin GJ, Kapfer C, Collins HH Jr., Formal SB. 1983. Alterations in the pathogenicity of Escherichia coli K-12 after transfer of plasmid and chromosomal genes from Shigella flexneri. Infect Immun 39: 1392-1402.

(31) Sansonetti PJ, Kopecko DJ, Formal SB. 1982. Involvement of a plasmid in the invasive ability of Shigella flexneri. Infect Immun 35: 852-860.

(32) Sasakawa C, Adler B, Tobe T, Okada N, Nagai S, Komatsu K, Yoshikawa M. 1989. Functional organization and nucleotide sequence of virulence Region-2 on the large virulence plasmid in Shigella flexneri 2a. Mol Microbiol 3: 1191-1201.

(33) Sasakawa C, Komatsu K, Tobe T, Suzuki T, Yoshikawa M. 1993. Eight genes in region 5 that form an operon are essential for invasion of epithelial cells by Shigella flexneri 2a. J Bacteriol 175: 2334-2346.

(34) Sasakawa C, Makino S, Kamata K, Yoshikawa M. 1986. Isolation, characterization, and mapping of Tn5 insertions into the 140-megadalton invasion plasmid defective in the mouse Sereny test in Shigella flexneri 2a. Infect Immun 54: 32-36.

(35) Sekiya K, Ohishi M, Ogino T, Tamano K, Sasakawa C, Abe A. 2001. Supermolecular structure of the enteropathogenic Escherichia coli type III secretion system and its direct interaction with the EspA-sheathlike structure. Proc Natl Acad Sci USA 98: 1163811643

(36) Sukhan A, Kubori T, Wilson J, Galan JE. 2001. Genetic analysis of assembly of the Salmonella enterica serovar Typhimurium type III secretionassociated needle complex. J Bacteriol 183: 11591167.

(37) Suzuki T, Sasakawa C. 2001. Molecular basis of the intracellular spreading of Shigella. Infect Immun 69:
5959-5966.

(38) Tamano K, Aizawa S, Katayama E, Nonaka T, ImajohOhmi S, Kuwae A, Nagai S, Sasakawa C. 2000. Supramolecular structure of the Shigella type III secretion machinery: the needle part is changeable in length and essential for delivery of effectors. EMBO J 19: $3876-3887$.

(39) Tamano K, Aizawa S, Sasakawa C. 2002. Purification and detection of Shigella type III secretion needle complex. Methods Enzymol 358: 385-392.

(40) Tamano K, Katayama E, Toyotome T, Sasakawa C. 2002. Shigella Spa32 is an essential secretory protein for functional type III secretion machinery and uniformity of its needle length. J Bacteriol 184: 1244 1252.

(41) Tampakaki AP, Fadouloglou VE, Gazi AD, Panopoulos NJ, Kokkinidis M. 2004. Conserved features of type III secretion. Cell Microbiol 6: 805 816.

(42) Tran Van Nhieu G, Ben-Ze'ev A, Sansonetti PJ. 1997. Modulation of bacterial entry into epithelial cells by association between vinculin and the Shigella IpaA invasin. EMBO J 16: 2717-2729.

(43) Tran Van Nhieu G, Caron E, Hall A, Sansonetti PJ. 1999. IpaC induces actin polymerization and filopodia formation during Shigella entry into epithelial cells. EMBO J 18: 3249-3262.

(44) Uchiya K, Tobe T, Komatsu K, Suzuki T, Watarai M, Fukuda I, Yoshikawa M, Sasakawa C. 1995. Identification of a novel virulence gene, virA, on the large plasmid of Shigella, involved in invasion and intercellular spreading. Mol Microbiol 17: 241-250.

(45) Venkatesan MM, Buysse JM, Oaks EV. 1992. Surface presentation of Shigella flexneri invasion plasmid antigens requires the products of the spa locus. J Bacteriol 174: 1990-2001.

(46) Yip CK, Kimbrough TG, Felise HB, Vuckovic M, Thomas NA, Pfuetzner RA, Frey EA, Finlay BB, Miller SI, Strynadka NC. 2005. Structural characterization of the molecular platform for type III secretion system assembly. Nature 435: 702-707.

(47) Zhao R, Pathak N, Jaffe H, Reese TS, Khan S. 1996. FliN is a major structural protein of the C-ring in the Salmonella typhimurium flagellar basal body. J Mol Biol 261: 195-208. 